\title{
Karjalaisten naisten esikristillinen nimistö
}

Nykyinen karjalaisten käytössä oleva naisten etunimisysteemi on vuosisataisen prosessin tulos. Tutkimuksia, jotka valaisisivat tämän systeemin kehitystä ja muodostumisprosessia, ei toistaiseksi ole. Kristillistä nimistöä koskevia havaintoja ja laajalle levinneiden naisten nimivarianttien listoja on nähtävissä muiden muassa Samuli Paulaharjun (1924), Viljo Nissilän (1976), Pertti Virtarannan (1972, 1992) ja Denis Kuzminin $(2016,2017)$ tutkimuksissa, mutta karjalankielinen esikristillinen naisten nimistö on jäänyt toistaiseksi täysin tutkimatta.

Ensimmäiset kirjalliset tiedot karjalaisten kristillisestä kasteesta ovat vuodelta 1227, jolloin Jaroslav Vsevolodinpoika käski kastamaan karjalaisia. Juuri tuosta ajasta lähtien voidaan puhua uuden uskonnon ja kristillisten nimien asteittaisesta tulosta Karjalaan. Noin 800 vuoden kuluessa karjalaiset ovat omaksuneet suuren määrän kristillisiä nimiä. Niistä on erilaisin konsonantti- ja vokaalimuutoksin muotoutunut karjalan kielessä useita hypokorismeja eli kansanomaisia nimivariantteja. Näitä hypokorismeja havainnollistavat asetelmat 1-2 (seur. sivulla).

\section{Esikristilliset nimet asiakirjoissa}

Ennen kristinuskon tuloa Karjalaan rautakautisilla karjalaisilla oli käytössään omaperäinen esikristillinen nimisysteemi, ja uuden nimisysteemin juurtuminen karjalan kieleen olikin pitkä prosessi. Toisaalta ainakin varhaisim- mat väestöluettelot 1500-luvulta kielivät, että jo tuolloin suurin osa miehistä kantoi kristillisiä etunimiä. Voi kuitenkin havaita, että miesten esikristillisiä nimiä, sekä omaperäisiä että muinaisvenäläisiä, oli käytössä karjalaisten keskuudessa vielä 1600 -luvun ensimmäisellä puoliskolla. ${ }^{1}$ Tästä esimerkkejä ovat vuonna 1618 Suojärven pogostan Hyrsylässä Jaakko Repånpoika ( ${ }^{*}$ Revon-) Putto, vuonna 1629 Tiuralan pogostan Lauroilassa Timoska Migriläinen ja hänen lapsenlapsensa Pervo (ven. Первой 'ensimmäinen') (IK 1993: 356, 364), vuonna 1631 Sortavalan pogostan Nukuttalahdessa Posko Offanasioff (IK 1987: 557) = Posnik Ofonasief (1618; IK 1987: 331), vuonna 1637 Sortavalan Madialassa Achti Ivanof (IK 1991: 375), Pälkijärven pogostan Illialassa Martyn Nyrick ${ }^{2}$ Kurkojev (IK 1991: 305, 676) ja

1. Vrt. karjalaiset kauppiaat Oulun satamassa vuonna 1553: Ignatta Sixtuksenpoika, Nousia Riionpoika, Musta, Vaseli Ihanpoika (Nevalainen 2016: 15); Fedko Vaskov syn Igameleva (ven. syn 'poika') (1500, Kurkijoki), Ivaško Novzujev (1500, Sortavala), Ignat Hyuetin (1554, Uukuniemi) (Nissilä 1975: 124-125, 127); 1600-luku: Iwanko Uskaloff, Clementi Ihanuxen, Griska Ihalembin, Ondruska Ihandioff, Semenko Ihaleij, Iliuska Leinoin, Iwana Måndoinen (1629, Korelan ujesti; IK 1993: 373), Jacuska Parandaioff (1631, Korelan ujesti; IK 1987: 484, 488, 505, 551); Åwärka Neuwoief (1637, Kirkko-Leppälaksi; IK 1991: 300), Simana Toiwiainen (1629, Korelan ujesti; IK 1993: 372), Hodari Wallituinen (1629, Korelan ujesti; IK 1993: 376), Petruska Wihottin (1638, Suistamo; Nissilä 1975: 124), Issaka Wiliakain (1618, Korelan ujesti; IK 1987: 347, 354).

2. Vrt. Kalevalassa mainittu metsän haltija Nyyrikki Tapionpoika ja vuonna 1637 karjalainen Dimitrejko Nyrakof (IK 1991: 300). 
Asetelma 1.

Maria-nimen hypokorismit karjalan kielessä.

\begin{tabular}{lllllll}
\hline Maarie & Maija & Maikki & Maču & Maka & Maki \\
\hline Man'a & Man'ka & Man'ke & Man'n’i & Man’oi & Man’u \\
\hline Man'ukka & Man'ukki & Manu & Mar’a & Mar’aša & Maraša \\
\hline Mard'a & Mar’o & Mar’u & Mari & Maria & Marija \\
\hline Marie & Marikka & Marikko & Marina & Mariška & Marja \\
\hline Marju & Marjuška & Maru & ${ }^{*}$ Mas’a & Maša & Maška \\
\hline Mašoi & Massa & Mašši & Mašukki & Miarjuška ${ }^{3}$ & Muarjuška \\
\hline Muari & Muarie & Muarii & Muarja & Muarjo & Muarjoi \\
\hline Muarju & Muard'a & Muaša & Muaški & Muuročka & Mååria ${ }^{4}$ \\
\hline
\end{tabular}

Asetelma 2.

Kristillisten naisten nimien eräät karjalankieliset hypokorismit.

\begin{tabular}{|c|c|c|c|}
\hline Атрі - Анбиса & Anс̌игі - Анна & $\begin{array}{l}\text { Auvuиsa- } \\
\text { Aвгуста }\end{array}$ & $\begin{array}{l}\text { С̌ikki- } \\
\text { Синклетикия }\end{array}$ \\
\hline Čokoi - Фёкла & Čolgana - Ольга & $\begin{array}{l}\text { Čolo - } \\
\text { Соломанида }\end{array}$ & ${ }^{\star} \check{C} e k u s ̌ a-$ Фёкла \\
\hline D’ougoi - Евгения & D’oukko - Евдокия & Feuri - Хавронья & Fiijo - София \\
\hline Gluašši - Клавдия & ${ }^{*}$ Hekka - Федора & Нерепі - Фетинья & Hiekla - Фёкла \\
\hline Норо - Хавронья & Hoto - Федора & Jeliita - Елизавета & ${ }^{\star}$ Јеиһо - Евгения \\
\hline Joutokei - Евдокея & Klakko - Клавдия & Klaučči - Клавдия & Kretu-Крестина \\
\hline $\begin{array}{l}\text { Кгірра - } \\
\text { Агриппина }\end{array}$ & Lyyči - Лидия & Mabu - Mapøa & $\begin{array}{l}\text { Мас̌čuri- } \\
\text { Матрена }\end{array}$ \\
\hline Magri - Мавра & Marčči - Mapøa & $\begin{array}{l}\text { Maršakka - } \\
\text { Mapøa }\end{array}$ & Miila - Людмила \\
\hline Миарра - Марфа & Načči - Наталья & $\begin{array}{l}\text { Nadin }(u)- \\
\text { Надежда }\end{array}$ & Nadžoi - Надежда \\
\hline Nари - Настасья & Niija - Агния & $\begin{array}{l}{ }^{*} \text { Оhпиг̌a - } \\
\text { Абанасия }\end{array}$ & Oiti - Евдокия \\
\hline
\end{tabular}

3. Leningradin alueen Konnun livviläismurteessa sekä Tverin alueen Vessin varsinaiskarjalaisessa murteessa ua-diftongin alkukomponenttina esiintyy takavokaali $i(u a \rightarrow i a)$. Äänne vastaa viron puolisuppeata illabiaalista keskivokaalia õ:tä. Vrt. mia (*mua), miamo (*muamo), tiatto (*tuatto), kialia (*kualua), litria (partitiivi *litrua).

4. Paatenen murteessa diftongi oa kehittyi pitkäksi vokaaliksi (*oa > oo); vrt. ååldo (*oaldo), såån (*soan) jne. Virtaranta on käyttänyt pitkän vokaalin merkitsemiseen åå-sekvenssiä. Sen poh-

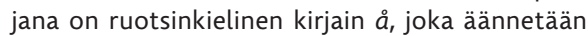
samaan tapaan kuin o Paatenen murteessa. Nykyisestä asusta voidaan kuitenkin päätellä, että sa- 1650-luvulla Liperin ${ }^{5}$ pogostan Taipaleessa Malafej Ihalempiof Kärkkänen (Saloheimo 2010: 200).

nassa oli käytössä alun perin diftongi ${ }^{*} o a$, mutta historiallisesti siinä on ollut pitkä $a a$.

5. Näyttää siltä, että myös Liperi-paikannimen pohjana on karjalainen esikristillinen nimi, vrt. karjalainen Liperå Muliakof (1618, Suojärven pogosta; IK 1987: 363); karj. libero 'pieni kala', liberö 'liehakoiva ihminen' (KKS), suku Liberi (ven. Libertsov) (Kuoččila, Aunuksen Karjala). 
Naisten nimiä esiintyy tuon ajan asiakirjoissa vain vähän, ${ }^{6}$ ja kaikki niissä olevat naisten nimet ovat jo kristillisiä. On kuitenkin yksi poikkeus: vuonna 1637 Kurkijoen pogostan Saviojan kylässä mainitaan Maima Ulasies Änckia (eli Vlas-nimisen miehen leski nimeltä Maima; IK 1991: 86), jonka nimi todennäköisesti on esikristillinen (vrt. karj. maima 'kalanpoikanen; pikkukala' $\rightarrow$ ${ }^{*}$ pienikasvuinen, pieni). Myös Karjalan ja sen naapuruston venäjänkielisillä alueilla esiintyy tuona aikana vain kristillisperäisiä naisten nimiä. Muualla Venäjällä sen sijaan tavataan naisten esikristillisiä nimiä toisinaan vielä $1600-l u v u l l a$, mitä havainnollistavat esimerkiksi vuodelta 1624 leski Seljanka (< miehen nimestä Seljanin, Seljata 'maanviljelijä, talonpoika') ja leski Smirenka ('hurskas, nöyrä) (RGADA 1624: 439 ob.-440) sekä vuodelta 1637 Pavel Potrakejev ja hänen vaimonsa Dosada ('harmi'). Asiakirjassa mainitaan, että Dosadalla on myös "rukousnimi" eli kristillinen etunimi Matrjona. (DG 1637: 2.) Tutkijoiden käytössä on myös ainutlaatuinen asiakirja nimeltä "Bežeckin ylängön karjalaisluettelo vuosilta 1650-51" (ks. Saloheimo 1992), joka kertoo noin 1200 karjalaisperheen vaiheista nykyisen Tverin alueen koillisosassa. Luettelossa on mainittu 1218 naispuolista henkilöä; joukossa on sekä naisia että tyttöjä. Tämä luettelo viittaa siihen, että mahdollisia venäläisperäisiä esikristillisiä nimiä käytettiin tuona aikana myös karjalaisnaisten keskuudessa. Tästä kertovat seuraavat nimiesimerkit:

6. Naisten nimet alkoivat ilmestyä Venäjällä säännöllisesti asiakirjoihin vasta kolmannen väestönlaskennan aikana eli 1760-luvun alussa. Tästä syystä naisten nimiä koskevia tietoja on varsin niukasti edellisten henkikirjoitusten ajalta. Naisista vain lesket esiintyvät asiakirjoissa, sillä leskeys antoi oikeuden olla juridisesti perheen pää ja hoitaa tämän velvollisuuksia.

7. Vrt. talonnimi Maimankodi ja suvun nimi Maima ja virallinen sukunimi Mal'kov (Мальков) (Tekaččula, Aunuksen Karjala).
Durka, Goriska, Kozjutka, Maresänka, Nasonilka, Onositsa, Salanko, Solwenko ja Ijelgija. (Saloheimo 1992.) Ei voi toki sulkea pois sitäkään mahdollisuutta, että joidenkin nimien takana on jokin kristillinen nimi, vaikka en ole löytänyt toistaiseksi niille vastaavia venäjänkielisiä kantamuotoja.

\section{Kansanrunous ja esikristilliset nimet}

Omaperäisiä esikristillisiä naisten nimiä ei esiinny Karjalan 1500- ja 160o-luvun asiakirjoissa edes venäläistyneessä muodossa. On kuitenkin tiedossa, että itämerensuomalaisen esikristillisen naisten nimistön päälähde on kansanrunous, muun muassa kalevalamittaiset runot, joista ovat peräisin Aino, Andamoine, Hermandone, Kapo, Kave, Kodžoi, Lokka ${ }^{8}$, Piltti, Rauni, Pal'loi (Pal'loni), Annikki, Mimerkki, Mielikki, Slavnikki, Tuulikki, Tuuvikki, Tyynikki, Tyytikki, Vuohikki, Hongatar, Kujotar, Kuutar, Lohetar, Loviatar (Loviotar), Marjatar, Ošmotar, Päivätär jne. (KEP 1950; SKVR). Verrattuna esikristillisiin miesten nimiin, joiden jälkiä on paitsi asiakirjoissa myös sukunimistössä, edellä mainitut naisten nimet ovat ainakin asiakirjojen perusteella täysin tuntemattomia. Kansanrunouden lisäksi on kuitenkin tarjolla eräs tärkeä lähde, josta voi ammentaa tietoja omaperäisistä naisten nimistä. Täyttä varmuutta ei tietenkään ole, mutta oman käsitykseni mukaan keskiaikaisia esikristillisiä nimiä on löydettävissä kotieläinten nimistä ja erityisesti kki-loppuisissa lehmännimistä (vrt. Aspelin 1886: 3; Forsman 1891: 190-192). Edellä esitetyt esimerkit kansanrunoudesta todistavat, että sama johdin esiin-

8. Setälän mukaan Ilmarisen äidin nimi Lokka voisi palautua skandinaaviseen Loke-nimeen (Turunen 1979: 185). Toisaalta nimi esiintyy usein Kajavaini-nimen rinnalla (vrt. karj. kajava 'lokki'). Huom. myös Låcki Jakoflef (1618, Lapinlahti, Kurkijoen pogosta; IK 1987: 311). 
tyy usein myös kansanrunoudessa tavattavissa naisten nimissä.

\section{Lehmännimistö karjalaisten asuma-alueilla}

Valmistellessani esitelmää karjalankielisistä lehmännimistä huomasin, että nautakarjan nimissä ilmenee osittain samoja kantoja kuin kansanrunoudessa esiintyvässä esikristillisessä naisten nimistössä. Entuudestaan jo tiedetään, että kristillisiä naisten nimiä käytetään sekä Karjalassa että Suomessa usein lehmien nimissä tietoja tästä on jo 1700-luvulta (Ojansuu 1912: 34). Täten voidaan varovaisesti päätellä, että sama on voinut päteä aiempaan nimistöön. Etunimistössä on 140o-luvulla saattanut tapahtua syvällinen murros. Todennäköisesti se oli sidoksissa uuden muodikkaan kristillisen etunimisysteemin laajaan käyttöönottoon itämerensuomalaisilla alueilla; entinen naistennimisysteemi ei kadonnut jäljettömiin vaan siirtyi toiseen tarkoitukseen. Olen siis sitä mieltä, että monen Karjalassa käytetyn lehmännimen takana on esikristillinen naisennimi. Vielä enemmän muinaisia nimiä voi löytyä Suomesta, todennäköisesti Virostakin. Karjalassa venäjän kielen ja naapurikansan vaikutus on jo pitkään ollut vahva kaikkialla - erityisesti eteläisessä Karjalassa. Se heijastuu muun muassa lehmännimistöön. Toisin sanoen nykyään livviläis-, lyydiläis- ja erityisesti varsinaiskarjalaisissa murteissa TytärKarjalassa (Leningradin ja Tverin alue) omaperäisiä lehmännimiä esiintyy vain harvoin, ja niiden tilalle ovat tulleet lainanimet venäjästä: Belka, Bel'ka, Pel'a 'valkoinen'; Rižuha 'punaruskea'; Pestruha 'kirjo', Buura, Buuroi, Buurikki 'tummanruskea'; Krasotka 'kaunikki''; Zor'ka ${ }^{10}$

9. Vrt. Kavnoef Mark (*Kauno; IK 1991: 725), huom. myös karjalainen lehmännimi Kaunoi, Kaunikki.

10. Vrt. Karjalan venäjänkielisissä saduis- 'rusko' eli 'aamuruskon aikana syntynyt'; Nočka 'yön aikana syntynyt', Marta 'maaliskuussa syntynyt' sekä Dun'a, Daška, Lukoi, Lukerju, Sil'va ja Maška, joiden pohjana ovat naisten nimet Jevdokija, Darja, Lukerja, Silvija ja Marija. 1900luvulla kukaan ei kerännyt Karjalassa johdonmukaisesti eläinten nimiä, vaikka osa nimistä löytyy esimerkiksi Karjalan kielen sanakirjasta (KKS). Tällä vuosikymmenellä lehmännimistöä on tutkinut Henna Massinen (2016), joka on esitellyt tuloksiaan Nimistöntutkimuksen päivillä pitämässään esitelmässä. Suurin osa hänen eteläisestä Karjalasta peräisin olevasta nimikokoelmastaan, joka on osin hänen itse keräämäänsä, on venäläistä perua.

\section{Kansanrunous, asiakirja-aineisto ja lehmännimet}

Suurin osa omaperäistä lehmien nimistöä on karjalan kielestä jo kadonnut jäljettömiin, ja myös tiedot muista mahdollisista esikristillisistä naisten nimistä ovat hävinneet. Osittain samoja nautakarjan nimiä kuin Karjalassa tavataan myös Suomen puolella, ja voidaan ainakin olettaa, että suomenkielisessä lehmännimistössä piileskelee mahdollisesti yhteisiä suomalaiskarjalaisia ja ylipäätään itämerensuomalaisia naistennimiä, jotka ovat ainakin 2000 vuotta vanhoja. ${ }^{11}$ Taulukkoon 1 on koottu

sa esiintyvä naisen nimi Zor'ka ja miehen nimi Zor'ka, Zoren'ka. Aunuksen Karjalan karjalankielisestä sukunimistöstä on tallennettu myös suvun nimi Zor'a (virallisesti Zorin; Miinala, Pappila, Suarimägi, Mägrie, Aunuksen Karjala), vrt. myös karjalainen Danilko Kirilov syn Zor'a (Umba, Kuolan niemimaa; RGADA 1678b: 760).

11. Oletetaan, että myöhäiskantasuomi eli itämerensuomalaisten kielten yhteinen kantakieli alkoi hajota ajanlaskumme alussa. Se, että osa lehmännimistöä karjalan, suomen, viron, inkeroisen ja vepsän kielessä on samanlaista, voi viitata siihen, että yhteinen naisten nimistö oli itämerensuomalaisella alueella olemassa jo ennen myöhäiskantasuomen hajoamista. 
Taulukko 1.

Lehmännimet ja samakantaiset esikristilliset henkilönnimet kansanrunoudessa.

\begin{tabular}{|c|c|c|c|}
\hline $\begin{array}{l}\text { Kansanrunous } \\
\text { (nimet) }\end{array}$ & Lehmännimet & $\begin{array}{l}\text { Kansanrunous } \\
\text { (nimet) }\end{array}$ & Lehmännimet \\
\hline $\begin{array}{l}\text { Ainikki' }{ }^{12}, \text { Aino; } \\
\text { Ainikki Turuzen- } \\
\text { poiga }\end{array}$ & $\begin{array}{l}\text { karj. Ainikki, Ainikko, } \\
\text { Aino } \\
\text { suom. Ainikki, Ainike }\end{array}$ & $\begin{array}{l}\text { Lyylikki (suksen- } \\
\text { tekijä), Lyylelline } \\
\text { (naishahmo) }\end{array}$ & suom. Lyylikki \\
\hline Kyllikki & $\begin{array}{l}\text { karj., suom. Kylli, } \\
\text { Kyllikki } \\
\text { ?karj. Kul'l'ikki }\end{array}$ & $\begin{array}{l}\text { Rivi-Sunni } \\
\text { (pojan nimi) }\end{array}$ & $\begin{array}{l}\text { ?suom. } \\
\text { Sun(n) ikki }\end{array}$ \\
\hline Mielikki & karj., suom. Mielikki & Annikki & suom. Annikki \\
\hline $\begin{array}{l}\text { Suovakko } \\
\text { (Pohjolan akka) }\end{array}$ & $\begin{array}{l}\text { ?karj. Suobikki, Suopo(i) } \\
\text { ?suom. Aikasuopa, } \\
\text { Suovi }\end{array}$ & $\begin{array}{l}\text { Šulkoi-Struunu } \\
\text { (pojan nimi) }\end{array}$ & $\begin{array}{l}\text { ?suom. } \\
\text { Ruunikki }\end{array}$ \\
\hline Tuulikki & suom. Tuulikki & Lemmingöine & $\begin{array}{l}\text { karj., suom. } \\
\text { Lemmikki }\end{array}$ \\
\hline Tellervo & suom. Tellervo & $\begin{array}{l}\begin{array}{l}\text { Pilvelline } \\
\text { (naishahmo) }\end{array} \\
\end{array}$ & $\begin{array}{l}\text { suom. Pilvikki, } \\
\text { Pilvi }\end{array}$ \\
\hline $\begin{array}{l}\text { Nyyrikki (metsän- } \\
\text { kuninkaan poika) }\end{array}$ & suom. Nyyrikki & $\begin{array}{l}\text { Hermando(ine) } \\
\text { (neitosen nimi) }\end{array}$ & ?suom. Hermikki \\
\hline $\begin{array}{l}\text { Joukoni, } \\
\text { Jolgamoine }\end{array}$ & suom. Joukonen & Maarjoi, Marjatar & $\begin{array}{l}\text { suom. Marjonen, } \\
\text { Marjanen }\end{array}$ \\
\hline $\begin{array}{l}\text { Aigamoine } \\
\text { (pojan nimi) }\end{array}$ & suom. Aikanen & Hiilo, Hiile & suom. Hiilikki \\
\hline Ilmori, Ilmarini & suom. Ilmikki & $\begin{array}{l}\text { Piili-Vilkuna } \\
\text { (neitonen) }\end{array}$ & suom. Vilkuna \\
\hline $\begin{array}{l}\text { Päivätär } \\
\text { (päivän jumalatar) }\end{array}$ & suom. Päivikki & $\begin{array}{l}\text { Tähetär } \\
\text { (yön jumalatar) }\end{array}$ & $\begin{array}{l}\text { karj. Tähikki, } \\
\text { Tiähti } \\
\text { suom. Tähikki, } \\
\text { Tähdikki }\end{array}$ \\
\hline Vetikkö (vetehinen) & ?suom. Vedikki & $\begin{array}{l}\text { Ošmoni, Osmari, } \\
\text { Ošmotar }\end{array}$ & Osmo (härkä) \\
\hline
\end{tabular}

sekä kansanrunoudessa että lehmännimistössä esiintyviä samakantaisia nimiä.Taulukossa 2 (s. 436) esitetään nimistössä ja asiakirjoissa esiintyvät henkilönnimet sekä samakantaiset lehmännimet karjalassa ja suomessa.

12. Vrt. venäjänkielinen esikristillinen miehen nimi Odinets, Jedinets (Одинеи, Единеи 'ainikki, ainoa'): seppä Odinets Ivanov (1568, Korelan kaupunki; IK 1987: 62), Ädinetz Jyiflef Ludianer (1629, Tiuralan pogosta; IK 1993: 378) sekä virallinen sukunimi lyydiläisalueella Odintsov (Čuppu, Martniemi, Munjärven kunta).

\section{Eläinaiheiset esikristilliset nimet}

Kansanrunous osoittaa, että muinaisten naisten nimien joukossa voi esiintyä myös eläinten nimiä (esim. Kaja-

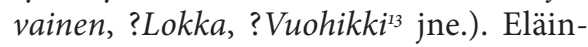

13. Vrt. nykyinen lehmännimi Aunuksen Karjalassa Kozočka (*Vuohikki; karj. vuohi - ven. 'koza' $\rightarrow$ karj. dem. vuohikki - ven. 'kozočka'). Seuraava karjalankielinen runo voi olla todisteena siitä, että keskiaikaisilla karjalaisilla oli käytössä nimi Vuohikki: "Šynty lapši nuorimmalla. Nuorimmalla pienimmällä. Mi hänellä nimekši pannah? Vuohikki, hyvä nimikki" (KEP 1950: 201). 
ten nimitykset esiintyvät ennen kaikkea miesten esikristillisessä nimistössä; ${ }^{14}$ vuonna 1618 Korelan ujestin (Käkisalmen läänin) Hyrsylässä on mainittu Jaakko Repånpoika ( ${ }^{*}$ Revon) Putto (IK 1987: 361), Suojärvellä Kondrato Kokonpoicha $^{15}$ (IK 1987: 360-361), vuonna 1629 Petkolassa Michitta Häränpoika (IK 1993: 356), vuonna 1631 Komperossa Cabris Obramoff, Riikolanvaarassa Cabris Iuanoff'vuohi, kapris' (IK 1987: 486, 496) ja vuonna 1637 Raholassa Jusko Oravanpoika (IK 1991: 73). Venäläisillä esiintyvät asiakirjoissa esimerkiksi sellaiset esikristilliset naisten nimet kuin Корова 'lehmä, Щука 'hauki', Курии, 'kana' jа Медведица 'emokarhu' (Stepanova 2006). Täten voidaan olettaa, että sellaiset karjalankieliset lehmännimet kuin Lokka, Hanhikki, Huahkoi (vrt. myös veps. Hahkoi) 'harmaa', Hiirikki ${ }^{16}$, Joučikki ?'joutsen', Kullikki ?'kuovi', Peip(p)o ${ }^{17}$ 'peippo' ja Lindoi 'lintu' olisivat voineet myös olla alun perin käytössä naisten niminä. Nähtävästi tähän ryhmään kuuluu myös lampaan nimi Tikki 'tikka'.

14. Esim. pojan liikanimi (alun perin äidin antama hellittelynimi) Čägäne (Suistamon Koitto), karj. čägä(ne) '(pieni) varsa'. Eräiltä veljeksiltä kysyttiin, kenen lapsia he olivat, ja he vastasivat: "Myö olemmo mamman čägäzii da vasikoi" (NA). Näyttää siltä, että tässä perheessä käytettiin kristillisten nimien asemesta eläinaiheisia hellittelynimiä. Tämä tieto voi olla jälkikaikua varhaisemmista ajoista, jolloin karjalaisilla oli esikristillinen etunimisysteemi, jonka osa jatkoi elämäänsä niin perhepiirin hellittelynimissä kuin myös liikanimissä.

15. Eräissä tapauksissa kyseessä voi olla lisänimi (esim. Pekko Puhasparranpoika, IK 1987: 290) tai myös suvun nimi. On myös tapauksia, joissa poika- ja nen-loppuinen asu vaihtelevat asiakirjoissa viitatessaan samaan asuinpaikkaan tai henkilöön (vrt. saman kylän asukkaat Hodari Mustanpoika ja Simana Mustonen, IK 1987: 377).

16. Vrt. nurmi Hiiroinluhtu (Sammatuz, Aunuksen Karjala); karj. hiiroi 'hiiri; hiirenharmaasta lehmästä' (KKS).

17. Vrt. suistamolainen naisen liikanimi Peippo. Hän oli lapsena hyvin pienikokoinen eli "pieni kuin peippo" (NA).
Taulukko 2.

Lehmännimet ja samakantaiset henkilönnimet nimistössä ja asiakirjoissa.

\begin{tabular}{|c|c|}
\hline Henkilönnimet & Lehmännimet \\
\hline $\begin{array}{l}\text { Mairi/la }{ }^{18} \text { (kylä, } \\
\text { 1618) (Sortavalan } \\
\text { pogosta) }\end{array}$ & $\begin{array}{l}\text { karj., suom. } \\
\text { Mairikki }\end{array}$ \\
\hline $\begin{array}{l}\text { Toivottu, Toivo } \\
\text { (Тойвутов) }\end{array}$ & $\begin{array}{l}\text { karj., suom. } \\
\text { Toivikki, Toivoi }\end{array}$ \\
\hline Mielitty & $\begin{array}{l}\text { karj., suom. Mie- } \\
\text { likki }\end{array}$ \\
\hline Joutsi & $\begin{array}{l}\text { karj. Joučikki, } \\
\text { Joučči suom. Jout- } \\
\text { sikki, Jouhtikki }\end{array}$ \\
\hline $\begin{array}{l}\text { Kyllätty } \\
\text { (Кюллетин) }\end{array}$ & $\begin{array}{l}\text { karj., suom. } \\
\text { Kyllikki }\end{array}$ \\
\hline $\begin{array}{l}\text { Viljakka } \\
(\text { Вильякин) }\end{array}$ & 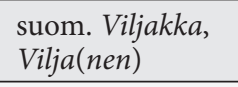 \\
\hline Ilmakka & suom. Ilmikki \\
\hline Merikirja & $\begin{array}{l}\text { suom. Merikki } \\
\text { suom. Kirjakka, } \\
\text { karj. Kirjo }\end{array}$ \\
\hline $\begin{array}{l}\text { Ihakka, } \\
\text { Ihala(inen) }\end{array}$ & suom. Ihanen \\
\hline Lieto & $\begin{array}{l}\text { suom. Lieto } \\
\text { (Kitee 1785) }\end{array}$ \\
\hline Lemmitty(inen) & $\begin{array}{l}\text { karj., suom. } \\
\text { Lemmikki, Lempi }\end{array}$ \\
\hline $\begin{array}{l}\text { Toija, pn. Toija/la } \\
\text { (kylä) }\end{array}$ & karj. Toijo \\
\hline Hyvö(nen), Hyväri & suom. Hyvikki \\
\hline Päiviö ${ }^{19}$, Päiväkkä & $\begin{array}{l}\text { karj. suom. } \\
\text { Päivikki }\end{array}$ \\
\hline
\end{tabular}

Suomenkin lehmännimistössä tavataan eläinten nimitykset Alli, Ahma, Tiira, Joukahainen (joukahainen 'joutsen'), Sotka ja Orava sekä vuohen nimenä Peippo (NA). Lehmien eläinaiheisia nimiä sekä vastaavanlaisia esikristillisiä naisten nimiä esiintyy myös Venäjällä (ks. taulukkoa 3).

18. Vrt. Korelan ujestissa Condrasko Mairoief, Sergiko Mairoieff (1631; IK 1987: 456, 529).

19. Vrt. kylä Päiwon Mäki (IK 1991: 344); karjalaiset Prokuska Päijwief, Griska Päiviev (1637; IK 1991: 177, 734); Iwann Päijwinen (1614, Kitee), Kusma Peiueinen (1560, Valkjärvi) (Nissilä 1975: 127). 
Taulukko 3.

Venäjänkieliset lehmännimet ja esikristilliset naisten nimet.

\begin{tabular}{l|l} 
Naisennimi & Lehmännimi \\
\hline Vorona & Vorona 'varis' \\
\hline
\end{tabular}

\begin{tabular}{l}
\hline $\begin{array}{l}\text { Lybed'(Лььбедь) Leb'odka 'joutsen' } \\
\text { Leb'odka }\end{array}$ \\
\hline
\end{tabular}

\begin{tabular}{ll}
\hline- & Lisa 'kettu, repo' \\
\hline Galka & Galka 'naakka' \\
\hline Perep'olka & $\begin{array}{l}\text { Perep'olka } \\
\text { 'viiriäinen' }\end{array}$ \\
\hline- & ?Belka 'orava' \\
\hline Soroka & Soroka 'harakka' \\
\hline ?Goluba & $\begin{array}{l}\text { ?Goluba } \\
\text { 'kyyhkynen' }\end{array}$ \\
\hline- & $\begin{array}{l}\text { Lastočka } \\
\text { 'pääskynen' }\end{array}$ \\
\hline
\end{tabular}

\section{Ihmisen ulkonäkö, luonne ja syntymäjärjestys}

Karjalaiset ovat asuneet pitkään rinnan venäläisten kanssa. Muinaisvenäläisiin nimiin kuuluvat muiden muassa sellaiset naisten nimet kuin Чеpнава 'musta', Беляна, Белуха 'valkoinen' ja Maлюma 'pieni'. Venäjän kielessä on samoja lehmännimiäkin. Ei siis voi sulkea pois mahdollisuutta, että itämerensuomalaisten keskuudessa on ollut käytössä sellaisia naisten nimiä kuin Mussikki ${ }^{2 \circ}$, Muššukki, Muštikoi tai Mustikki², Mus'a, Pienikki,

20. Vrt. Iwan Simanoff Mussikain (1618; IK 1987: 357), Stepantko ja luantko Mussikoff (1631; IK 1987: 509), kylä Mustilanmäki (1631; IK 1987: 401), Hodari Mustanpoika (1618; IK 1987: 377).

21. Vrt. karj. lampaan nimi Musturi 'musta lammas' sekä Ivanko Mikiforov Mustar (1563, Šungun pogosta) (PKOP: 149), Sauka Mussarin = Savka Muzurin (IK 1991: 309, 678) $\rightarrow$ henkilönnimi *Musari, *Musuri, *Musturi sekä myös karjalainen kauppias nimeltä Musta Oulun satamassa vuonna 1553 (Nevalainen 2016: 15).
Rusko(i), Ruško ja Bel'ka ${ }^{23}$ 'valkoinen lehmä. Suomalaisilla on puolestaan lehmänniminä Valkonen, Valko ja Valkuna. Karjalaisilla taas on hevosennimi Valko ${ }^{24}$ ja poron nimi Valkie sekä lampaan nimi Mučukki 'musta'.

Tämän ohella muinaisvenäläisten miesten nimissä on sellaisia, jotka viittaavat poikien syntymäjärjestykseen ${ }^{25}$ tai syntymäajankohtaan, esimerkiksi Первой (Pervoi) 'ensimmäinen', Второй (Vtoroi) 'toinen', Третьяк (Треня) (Tretjak, Tren'a) 'kolmas', Четвертак (Četvertak) 'neljäs', Пятой (P'atoi) 'viides' sekä Cepeda ${ }^{26}$ (Sereda) 'keskiviikko', Суб(б)отка (Sub(b) otka) ${ }^{27}$ 'lauantai', Поздей (Pozdei) 'myöhäinen lapsi' ja Меншuк (Menšik) 'nuorempi tai nuorin poika'. Vastaavia lainanimiä on esiintynyt myös karjalaismiehillä, mihin viittaavat esimerkiksi Pervo 'ensimmäinen'28: Pärwoi Räsenpoika (1618, Låukusenkylä, Sortavalan pogosta; IK 1987: 326), Perwoi Luiga (1618, Uukuniemen pogosta; IK 1987: 334); Tren'u(i) ('kolmas'): nurmen nimi Tren’uižennurmi 'Kolmannennurmi' (Vennyr, Vuohtjärven

22. Vrt. karjalaiset Petrusa Ruskoief, Makarei Ruskoff (= Ruskiain) (1618; IK 1987: 312, 373), Sen'ka Kozmin Ruškejev (1678, Kibo, Repolan pogosta) $\leftarrow$ *Ruškie, *Ruško(i) (RGADA 1678a: 121).

23. Belo Iwanof, Rigaria Bäla (1618, Korelan ujesti; IK 1987: 294, 308), ven. belyj 'valkoinen'.

24. Vrt. karj. sukunimi Halli (ven. Hallijv) (Valoilu, Aunuksen Karjala), myös karjalainen Halei Semenof (1618, Korelan ujesti; IK 1987: 293) ja karj. halli'valkoisen koiran nimenä' (KKS) sekä Lijna Loikanen $(1618$, Korelan ujesti; mts. 291) $\leftarrow$ hn. *Liina 'vaaleatukkainen'; karj. liinaharja 'vaaleaharjainen hevonen, liinakko' (KKS).

25. Vrt. kissanpentujen karjalankieliset nimet $Y t t i$ 'ensimmäisenä syntynyt', Totti 'toisena syntynyt'.

26. Vrt. virallinen sukunimi Seredin (Ruva, Soukelo; Vienan Karjala).

27. Vrt. karjalaiset Subotka Koreljanin (= karjalainen) ja Subotka Petrov (1597, Paanajärven pogosta; IK 1987: 217), myös hevosennimi Tverin Karjalassa: Subotka 'lauantai; ? lauantaina syntynyt'.

28. Vrt. vepsäläinen kylä Pervakoi (ven. Pervakovo) $\leftarrow$ ven. Pervak 'perheeseen ensimmäisenä syntynyt'. 
kunta); Piättö, Piätöi, Pättöi ('viides'): kylänosa Piättöilä (Valaisjoki, Kiestengin kunta), nurmen nimi Pättöilänkoda (Säämäjärvi); henkilönnimi Zubottu 'lauantai': kylän nimi Zubottalu (Aunuksen Karjala); *Posto: Postosen Samuila (1618, Korelan ujesti; IK 1987: 322); *Menšikka: Mensika Jormoief, Bogdan Mensikain (1618, Korelan ujesti; mts. 289, 299); Menšo: suojärveläinen suku Menšonen (ven. Menšakov; Patronen 2017: 194). Kun sitten tarkastellaan karjalaista lehmännimisysteemiä, huomataan, että siinä tavataan sellaiset nimet kuin Enčikki, Enčoi ${ }^{29}$, Endžikki, Endžoi, Ensoi, Ensikkö, Ensikkiº 'maanan-

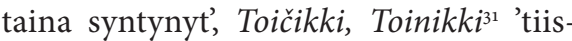
taina syntynyt', Kolm(u)oi ${ }^{32}$ 'keskiviikkona syntynyt', Piäšsikki, Piätkö̈ ${ }^{33}$ 'perjantaina syntynyt'. Olisiko mahdollista, että joidenkin edellä mainittujen nimien takana olisi esikristillinen naisennimi? Tässä on syytä mainita, että syntymäjärjestykseen viittavia nimiä tavataan karjalan kielessä nimenomaan lehmien, ei härkien nimissä.

Taulukkoon 4 olen koonnut venäläiset esikristilliset naisten nimet ja samanmerkityksiset karjalan- ja suomenkieliset lehmännimet. Oletan, että viimeksi mainituissa saattaa olla myös itämerensuomalaisia naisten nimiä

Voi varovaisesti otaksua, että Venäjälläkin esikristillisiä naisten nimiä alettiin joskus keskiajan ja uuden ajan taitteessa

29. Vrt. karjalaiset Entzo Jakoflef, Kanana Entzonpoika, Hilo Ensonpoika (1618, Korelan ujesti; IK 1987: 305, 364, 374), Stepantko Entzioff (1631, Korelan ujesti; mts. 508), Ivanko Enčojev (1637, Ko-

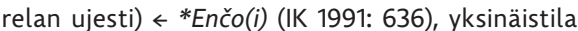
Endžinkondu (Juustjärvi, Aunuksen Karjala).

30. Vrt. autio Änsikass Ödhe (1637, Korelan ujesti) ${ }^{*}$ Ensikkä (IK 1991: 430).

31. Vrt. kylän nimi Toinino Korbassa (1500, Korelan ujesti) ${ }^{*}$ Toinen (PKVP 1851: 549).

32. Vrt. karjalainen Juško Dmitrijev Kolmojev (1678, Roukkula, Repolan pogosta) (RGADA 1678a: 127), Terentiko Kalmin $\rightarrow$ ? *Kolmin (1618, Korelan ujesti; IK 1987: 362) $\leftarrow$ *Kolmo(i).

33. Vrt. Pätko Jakovlef (1618, Korelan ujesti;/K 1987: 321); kylä Pätkujevo na Olontse (1582/83, Aunuksen Karjala) (IK 1993: 46).
Taulukko 4.

Esikristilliset naisten nimet venäjän kielessä ja samamerkityksiset lehmännimet karjalassa ja suomessa.

\begin{tabular}{l|l}
$\begin{array}{l}\text { Venäläiset esikristil- } \\
\text { liset naisten nimet }\end{array}$ & Lehmännimet \\
\hline $\begin{array}{l}\text { Goluba 'hellä, } \\
\text { lempi' }\end{array}$ & $\begin{array}{l}\text { karj. Heluna, } \\
\text { suom. Hellikki }\end{array}$ \\
\hline $\begin{array}{l}\text { Gostena 'vieraanva- } \\
\text { rainen' }\end{array}$ & $\begin{array}{l}\text { ? karj. Gostikki, } \\
\text { Kostikki }\end{array}$ \\
\hline Dobrava 'hyvä' & suom. Hyvikki \\
\hline $\begin{array}{l}\text { Ždana '(kauan) } \\
\text { odotettu' }\end{array}$ & karj. Toivikki \\
\hline Belava 'valkoinen' & suom. Valkonen \\
\hline Mal'uta 'pieni' & karj. Pienikki \\
\hline Zabava 'lystikäs' & karj. Lysti(kki) \\
\hline Cernav(k)a 'musta' & karj. Mussikki \\
\hline L'uba(va) 'lempi' & karj. Lemmikki \\
\hline Milava 'sievä' & suom. Sievä(kki) \\
\hline $\begin{array}{l}\text { Smirenka 'kaino, } \\
\text { kiltti' }\end{array}$ & $\begin{array}{l}\text { suom. Kaino, } \\
\text { Kiltti }\end{array}$ \\
\hline $\begin{array}{l}\text { Nadežda 'toivottu, } \\
\text { *haluttu' }\end{array}$ & karj. Haluna \\
\hline
\end{tabular}

\section{Taulukko 5.}

Lehmännimet ja samakantaiset esikristilliset naisten nimet venäjän kielessä.

\begin{tabular}{ll} 
Naisennimi & Lehmännimi \\
\hline Ždana & Ždanka \\
\hline Zabava & Zabava \\
\hline L'ubava & L'ubava \\
\hline Ves'ola & Ves'lka \\
\hline Belava & Belava \\
\hline Beluha & Beluha \\
\hline Bažena & Bažena \\
\hline L'uba & L'ubka \\
\hline Darena & Darenka \\
\hline Milana & Milka \\
\hline Blažena & Blažnaja \\
\hline Kudra & Kudra \\
\hline
\end{tabular}


Asetelma 3.

Venäjänkielisiä miesten nimiä, joiden merkitys on pejoratiivinen tai väheksyvä.

\begin{tabular}{|c|c|c|c|}
\hline Bolvan 'tolvana' & $\begin{array}{l}\text { Draka } \\
\text { 'tappelu(pukari)' }\end{array}$ & Durak 'hullu' & $\begin{array}{l}\text { Zamarai 'sotta- } \\
\text { pytty' }\end{array}$ \\
\hline Zloba 'kiukkuinen' & $\begin{array}{l}\text { Nerada 'surumie- } \\
\text { linen' }\end{array}$ & $\begin{array}{l}\text { Neugod 'vastenmie- } \\
\text { linen' }\end{array}$ & $\begin{array}{l}\text { Nekras/Nekrasa } \\
\text { 'ruma' }\end{array}$ \\
\hline $\begin{array}{l}\text { Neždan/Neždana } \\
\text { 'odottamaton' }\end{array}$ & $\begin{array}{l}\text { Neuliba 'hymytön } \\
\text { nainen' }\end{array}$ & $\begin{array}{l}\text { Nel'uba 'epämielui- } \\
\text { nen' }\end{array}$ & $\begin{array}{l}\text { Nesmejan/Nesme- } \\
\text { jana 'nauramaton, } \\
\text { nauruton' }\end{array}$ \\
\hline $\begin{array}{l}\text { Neusipa 'valpas, vä- } \\
\text { symätön' }\end{array}$ & $\begin{array}{l}\text { Nesgovorka 'taipu- } \\
\text { maton; joustama- } \\
\text { ton' }\end{array}$ & $\begin{array}{l}\text { Neustroj 'rikkinäi- } \\
\text { nen; huonokun- } \\
\text { toinen' }\end{array}$ & $\begin{array}{l}\text { Neupokoj 'rauha- } \\
\text { ton, levoton' }\end{array}$ \\
\hline $\begin{array}{l}\text { Nedobroj 'tyly; vi- } \\
\text { hamielinen' }\end{array}$ & $\begin{array}{l}\text { Neudača 'huono } \\
\text { onni; epäonni' }\end{array}$ & Oluh 'tollo' & Plohoj 'paha' \\
\hline
\end{tabular}

\section{Asetelma 4.}

Hevosten ja nautakarjan nimet Suomessa.

\begin{tabular}{llll} 
Hituva & Huima & Kiivas & Kipakka \\
\hline Kiukku & Kiista & Kovasuu & Laiska \\
\hline Lempo & Raju & Ruma & Tuima \\
\hline Vikuri & Villi & Äkimys & Äksy \\
\hline Ärjy & Laiskuri (sonni) & Melu (vasikka) & Pintelö (lehmä) \\
\hline Pöljä (lehmä) & Tappiaivo (lehmä) & Telmikki (lehmä) & Tuiska (lehmä) \\
\hline
\end{tabular}

käyttää lehmänniminä. Tätä oletusta vahvistavat taulukkoon 5 kootut esimerkit naisen- ja lehmännimien samankaltaisuuksista.

\section{Olivatko kaikki esikristilliset nimet sisällöltään myönteisiä?}

Muinaisvenäläisissä miesten nimissä on koko joukko merkitykseltään pejoratiivisia tai väheksyviä nimiä; niitä on esitelty asetelmassa 3. Taaskaan ei voi sulkea pois sitä mahdollisuutta, että itämerensuomalaisilla olisi ollut käytössä merkitykseltään vastaavanlaisia nimiä. Tiedossani ei toistaakseni ole tällaisia miesten nimiä, ${ }^{34}$

34. Novgorodissa vuosiin 1396-1409 ajoitetusta maakerroksesta löydetyssä tuohikirjeessä on mainittu laatokankarjalainen Vigar' (PIOK 1990: 83), jonka nimi voitaneen palauttaa muotoon *Vihari $(? \leftarrow$ mutta karjalaisissa sukunimissä sen sijaan on konnotaatioltaan kielteisiä tai halventavia nimiä. ${ }^{35}$

Lehmien karjalankielisissä nimissä ei ole merkitykseltään selvästi pejoratiivisia: ${ }^{36}$ sellaisia ei ainakaan ole tiedossani.

viha), vrt. myös itämerensuomalaiset esikristilliset nimet *Viha, *Vihattu, *Viho(i), *Vihava, *Vihavaino.

35. Esim. seuraavat sukujen nimet Aunuksen Karjalassa: Čučču - Čuččujev (Kuaroilu) $\leftarrow$ čučču 'höperö, hupsu'; Hoppu - Goppujev (Huutselgy) $\leftarrow$ hoppu 'riita, riitainen'; Varoi - Voronin (Padžalu) $\leftarrow$ varoi 'mämmikoura'; Piru - Pirujev (Jessoilu) piru 'paholainen'; Ryččy (Jänöiselgy) $\leftarrow$ ryččy 'raihnas, ruma' jne.

36. Vrt. kuitenkin pelto Kuilakki (Nekkula, Aunuksen Karjala) $<$ karj. kuilakkane, kuilas hevosesta: 'raju, raisu; pelkurimainen' (KKS) ja Karjalan venäläistyneellä alueella Kontupohjan piirissä esiintyvä uppiniskaisen lehmän nimi Kran'ka, jonka nimessä voidaan todennäköisesti nähdä samaa sanakantaa kuin sanassa krän'kiskö 'riitainen, epäsopuinen'. 
Suomessa tällaisia nimiä sen sijaan on erityisen runsaasti hevosten nimissä (ks. asetelmaa 4 ed. sivulla).

Kun kerran lehmien nimissä on ihmisten nimiä, olisiko mahdollista, että myös hevosten nimiin sisältyisi esikristillisiä omaperäisiä nimiä - myös naisten nimiä? Ainakin edellä mainitut muinaisvenäläiset nimet voisivat viitata tähän.

\section{Päätäntö}

Kaikki edellä mainittu mielestäni osoittaa, että muinaiskarjalaisten ja Venäjän luoteisosan slaavilaisten henkilönnimistössä on ilmeisiä yhteisiä piirteitä, jotka ovat syntyneet todennäköisesti ammoisten kontaktien tuloksena. Tästä johtuen on syytä kiinnittää huomiota vielä esikristillisiin kaksiosaisiin nimiin: karjalaiset Munomel (1369-1382), Mundanaht (1300-luku; PIOK 1990: 82-83), Spirko da Larivonko Vaskovy deti Igameleva (1500, Kurkijoki), Gaurilka Satamieli (1592, Kitee; Nissilä 1975: 124), Trochkima Satamiell (1618, Liperi), Griska Ihalembin (1630-luku; IK 1987: 349, 484), Malafej Ihalempiof Kärkkänen (1650-luku; Saloheimo 2010: 200), pelto Mielikirja $\left(\leftarrow\right.$ hn. ${ }^{\star}$ Mielikirja) ja saari Mielikieli $\left(\leftarrow \mathrm{hn} .{ }^{*}\right.$ Mielikieli) (Paanajärven Kuorilaksi). Elleivät kaksiosaiset yksilönnimet ole olleet omaperäisiä itämerensuomalaisten keskuudessa, voisi olettaa, että muinaiskarjalaiset omaksuivat kaksiosaisen etunimisysteemin todennäköisimmin slaaveilta eli muinaisnovgorodilaisilta (vrt. muinaisvenäiset nimet Vladi-mir, Vse-volod, Jaro-slav, Miro-ljub jne.), vaikka tiedetäänkin, että vastaavanlainen nimisysteemi oli laajalti käytössä myös germaaneilla. Mielestäni tällainen oletus tuntuu loogiselta, koska kantasuomalainen (eli itämerensuomalaisten) sydänalue oli aikoinaan Inkerinmaalla eli nykyisen Leningradin alueen länsiosassa, jossa käsitykseni mukaan oli aktiivisia suomalais-slaavilaisia kontak- teja ensimmäisen vuosituhannen viimeisellä neljänneksellä tai 1000 -luvun taitteessa. Nämä kontaktit ilmenevät muun muassa henkilönnimistössä. On hyvin mahdollista, että muut itämerensuomalaiset kansat, kuten esimerkiksi muinaissuomalaiset, omaksuivat vastaavanlaisen nimisysteemin alun perin juuri slaaveilta. Vaikuttaa siltä, että vasta myöhemmin, 1000-luvun ensimmäisillä vuosisadoilla, suomalaisille jo entuudestaan tuttu nimisysteemi sai Suomessa "toisen elämän" mutta tällöin skandinaavien välityksellä. Kaksiosainen etunimisysteemi saattaakin olla karjalaisalueilla siis slaavilaista eikä germaanista perua. On myös syytä mainita, että Ruotsissa kaksivartaloinen sekä henkilöä että sukua ilmaiseva nimityyppi oli vallitsevana 70o-luvulta saakka (Maliniemi 1947: 44). Onkin tärkeää huomata, että itämerensuomalaiset ja slaavilaiset kaksiosaiset nimet ovat luonteeltaan toisenlaisia kuin "sotaisat" germaaniset. On mahdollista, että kaksiosaisia nimiä oli käytössä myös naisten nimissä. Siihen voivat viitata esimerkiksi kaksiosaiset lehmien nimet ja epiteetit: vrt. karj. Aikašuopo, valkiepiä, Valkiepiä, Muštapiä, piirtopiä, Piirtopiä 'laukkiotsainen', šinivilla, šipšakarva, sipsukarva 'pilkkukarva' (KKS); suom. Aikasuopa, Ilokukka, Kaunispää, Kultasilmä, Kultasuu, Merenhelmi, Mustasilmä, Onnenpäivä, Äkkijyrkkä (Ojansuu 1912).

Karjalankielisen eläintennimistön tutkiminen on lupaava suuntaus, joka voi lisätä huomattavasti tietoamme karjalaisesta ja ylipäätään itämerensuomalaisesta esikristillisestä etunimisysteemistä. Nykyisten lehmännimien ja esikristillisten naisten nimien keskinäinen yhteys on toistaiseksi työhypoteesi, joka on mahdollisuuksien mukaan todistettava oikeaksi. Tämä edellyttää erikoistutkimusta, jonka puitteissa analysoidaan muun muassa eläintennimien sisältöä ja samalla mietitään esimerkiksi sitä, miksi mikäkin nimi annettiin vasikoille ja olisiko tyttö voi- 
nut saada vastaavanlaisen nimen. Näyttää siltä, ettei kaikkia lehmänniminä tunnettuja nimityksiä ole käytetty naisten esikristillisessä etunimistössä. Osa niistä syntyi ilmeisesti eri aikoina ja eri alueilla olemassa olleen $k k i$-johtimisen nimeämismallin mukaan. Toisaalta hyvä esimerkki on karjalainen lehmännimi Tähikki, Tiähti (suom. Tähdikki 'täpläotsainen'). Lehmännimenä se viittaa eläimeen, jonka otsalla on tähdenmuotoinen täplä, joten samanlaista nimeä tuskin voi antaa lapselle. Karjalan kielessä sana tähti, tiähti tunnetaan kuitenkin myös merkityksessä 'syntymämerkki' ${ }^{37}$ (KKS), joten mahdollisuus antaa tytölle ammoisina aikoina nimeksi Tähikki, Tiähti $3^{8}$ vaikuttaa varsin uskottavalta.

Lopuksi mainittakoon, että Nikolai Tupikovin (1903) venäläisiä esikristillisiä nimiä käsittelevässä sanakirjassa on tietoa noin 6000 nimestä. Voi siis olettaa, että itämerensuomalaisessa kulttuurissakin (mm. Karjalassa) vastaavanlaisten nimien määrä on ollut melkoinen. Jos oletukseni pitää paikkansa, nykyiseen kotieläinten nimistöön (mm. nautakarjan nimistöön) sisältyy ainakin osa rautakautisesta ja keskiaikaisesta esikristillisestä naistennimistöstä. Toisin sanoen edellä mainittujen karjalankielisten lehmien nimien lisäksi voi löytyä muitakin mahdollisia omaperäisiä rautakautisia ja keskiaikaisia naisten nimiä, ${ }^{39}$ esimerkiksi Čomikki,

37. Vrt. kuvaannollinen nimi eräässä karjalankielisessä runossa: "[nimet] panen iče pačkahutan, yhellä panen Väinämöisen, toisella Keškišynnyntähti" (KEP 1950: 30).

38. Vrt. sukunimi Zvezdin (ven. zvezda 'tähti') (Hamala, Artoila, On'kula, Aunuksen Karjala) $\rightarrow$ karj. *Tiähti.

39. Eläintennimistössä on joukko ri-loppuisia nimiä: esim. hevoset karj. Vihuri, suom. Hilpari, lammas Musturi, koirat karj. Löppöri, suom. Tomuri, lehmät karj. Kukkeri, suom. lehmä Vaipuri, sonni Junkkari. Tässä voidaan kiinnittää huomiota mm. vuonna 1631 Käkisalmen läänin karjalaiseen nimeltä Fedorko Junkarj (IK 1987: 452). Tiedetään myös, että johdin esiintyy toistuvasti esikristillisessä nimistössä, esim. Hyväri, Ilmori, Osmori, Toivari sekä
Čommi ${ }^{40}$, Halikki, Hamu(kki) (lampaannimi), Helleri, Helmi(kki) ${ }^{41}$, Hermikki, Hiilikki, Kauni(kki), Kirjikki, Komi, Kortikki, Liipakko, Lysti(kki), Mahikki, Mansikki, Mandžikki², Onnikki, Orvikki, Orvokki, Perjakka, Piirikki, Päičikki, Rainikki, Rutvikki, Šimpukka, Sorokki ja Toirikki.

\section{Denis KuZMin kusmiccu@hotmail.com}

Kirjoittaja on tutkija Helsingin yliopistossa ja Karjalan tiedekeskuksessa Petroskoissa.

\section{Lähteet}

Aspelin, Johannes Reinhold 1886:

Nautaeläinten nimistö - Uusi Suometar 91 s. 3. URL: https://digi.kansalliskirjasto. fi/sanomalehti/binding/26991? page=3.

DG 1637 = Духовная грамота 1637 года.

Отдел рукописей Российской государственной библиотеки в Москве. Ф. 256, Кн. 47, ед. 238.

Forsman, August Valdemar 1891: Tutkimuksia Suomen kansan persoonallisen nimistön alalta I. Pakanuuden aikainen nimistö. Yliopistollinen väitöskirja. Hel-

jo edellä mainittu laatokankarjalainen Vigar' ${ }^{*}{ }^{2}$ ihari; PIOK 1990: 83). Täten en pidä mahdottomana, että nykyisten kristillisten ri-loppuisten nimien joukossa on myös naisten esikristillisiä nimiä (vrt. naisten nimet Ančuri - Anna, Maččuri - Matr'ona; miesten nimet livari - Ivan, Tokari, Tokkuri Trofim). Tässä onkin mainittava, ettei kristillisissä nimissä aina voida selittää sitä, millä perusteella ri-johdin esiintyy missäkin näistä nimistä. On mahdollista, että esikristillisiä nimiä on piilossa myös eräissä kki-loppuisissa kristillisissä etunimissä (esim. Liššukki - Jelizaveta, Malokki - Melanija, Solokki - Solomonija). Vrt. myös tässä inkeroisessa esiintyvä naisen nimi Oudekki - Jevdokija ja suomalainen lehmän nimi Outeri).

40. Vrt. karj. sukunimi Čommi (ven. Čomin; Hattu, Aunuksen Karjala) vrt. myös karj. čomikki 'keimailija, hemmoteltu'.

41. Vrt. kylä Helmelä (1631, Korelan ujesti; IK 1987: 425) ja epävirallinen karjalankielinen suvun nimi: Helmini (suom. Helminen; Paanajärvi, Vienan Karjala).

42. Vrt. Mantzikala, kylä Korelan ujestissa (1618; IK 1987: 318). 
sinki: Suomalaisen Kirjallisuuden Seura.

IK 1987 = История Карелии XVI-XVII вв. в документах. Т. 1. Ред. А.И. Копанев \& А. Г. Маньков. Петрозаводск; Йоенсуу.

IK 1991 = История Карелии XVI-XVII вв. в документах. Т. 2. Ред. И. А. Чернякова и др. КарНЦ РАН. Петрозаводск Йоэнсуу.

IK 1993 = История Карелии XVI-XVII вв. в документах. Т. 3. Ред. И. А. Чернякова, К. Катаяла. КарНЦ РАН. Петрозаводск - Йоэнсуу.

КЕР 1950 = Карельские эпические песни. Москва-Ленинград: Издательство Академии наук СССР.

$\mathrm{KKS}=$ Karjalan kielen sanakirja I-VI. Helsinki: Suomalais-Ugrilainen Seura. LSFU XVI. 1968-2005.

Kuzmin, Denis 2016: Христианские имена карелов. - Вопросы ономастики. 13(2) s. $56-86$.

2017: Adaptation of orthodox personal names in the Karelian language. - Terhi Ainiala \& Janne Saarikivi, (toim.), Personal name systems in Finnic and beyond s. 137-184. Uralica Helsingiensia 12. Helsinki: Suomalais-Ugrilainen Seura.

Maliniemi, Aarno 1947: Henkilönnimet esihistoriallisena ja katolisena aikana. Hannes Teppo \& Kustaa Vilkuna (toim.), Etunimikirja s. 40-57. Tietolipas 5. Helsinki: Suomalaisen Kirjallisuuden Seura.

Massinen, Henna 2016: Karjalaisia eläimennimiä eilen ja tänään. Esitelmä Nimistöntutkimuksen päivillä. Helsinki, 17.-18.11.2016.

$\mathrm{NA}=$ Nimiarkisto. Kotimaisten kielten keskus. Helsinki.

Nevalainen, PeкKa 2016: Kulkukauppiaista kauppaneuvoksiin. Itäkarjalaisten liiketoiminta Suomessa. Helsinki: Suomalaisen Kirjallisuuden Seura.

Nissilä, Viljo 1975: Suomen Karjalan nimistö. Joensuu: Karjalaisen kulttuurin edistämissäätiön julkaisuja.

_ 1976: Suomen Karjalan ortodoksinen nimistö. Eripainos Viipurin suomalaisen kirjallisuusseuran toimitteista I. Lappeenranta: Viipurin suomalainen kirjallisuusseura.

OjansuU, Heik i 1912: Kotieläintemme suomenkielinen nimistö. Helsinki: Kirjapaino-osakeyhtiö Sana.

Patronen, Outi 2017: Rajakarjalaisen sukunimistön kehittyminen osana Suomen karjalankielisen ortodoksivähemmistön suomalaistumista 1818-1925. Helsinki: Helsingin yliopisto. http://urn. fi/URN:NBN:fi-fe201306113935 http:// hdl.handle.net/10138/39960.

Paulaharju, Samuli 1924: Syntymä, lapsuus ja kuolema. Vienan-Karjalan tapoja ja uskomuksia. Kalevalaseuran julkaisuja 2. Helsinki: WSOY.

PIOK 1990 = Письменные известия о карепах. С.И. Кочкуркина, А. М. Спиридонов \& Т.Н. Джаксон. Петрозаводск: Издательство Карелия.

PKVP 1851 = Переписная окладная книга Водской пятины 7008 (1500) года. Часть 2. Временник Московского общества истории и древностей российских. Москва: Университетская типография.

RGADA $1624=$ Дозорная книга Тюмени. Российский государственный архив древних актов. - Ф. 214, Кн. 5. Москва.

RGADA $1678 \mathrm{a}=$ Переписная книга Кольского уезда корельских Ребольских волостей стрелецкого головы Кольского острога Ивана Власова сына Стариова 1678 года. - Российский государственный архив древних актов. - Ф. 1209. Оп. 1. Д. 15056. Москва.

RGADA 1678b: Переписная книга Двинского уезда переписи стольника Афанасия Даниловича Фонвизина и подъячего Федора Замятина 1678 года. - Российский государственный архив древних актов. - Ф. 1209. Оп. 1. Москва.

Saloheimo, Veijo 1992: Bezhetskin ylängön karjalaisluettelo vuosilta 1650-51. Karja- 
lan tutkimuslaitoksen monisteita nro 5. Joensuu: Joensuun yliopisto.

- 2010: Entisen esivallan alle uusille elosijoille. Ortodoksikarjalaisten ja inkeroisten poismuutto 150o- ja 160o-luvuilla. Joensuu: Pohjois-Karjalan historiallinen yhdistys.

SKVR = Suomen kansan vanhat runot. URL: https://skvr.fi/ (15.1.2019).

Stepanova, F. V. 2006: Русский женский антропонимикон в культурно-генетическом аспекте: диссертация на соискание ученой степени кандидата филологических наук. Краснояр. гос. ун-т. Лесосибирск, 2006. http:// www. lib.ua-ru.net/diss/cont/180473.html

(23.12.2018).

Tupikov, N. M. 1903: Словарь древнерусских личных собственных имен. Санкт-Петербург: Типография И.Н. Скороходова.

Turunen, Aimo 1979: Kalevalan sanat ja niiden taustat. Lappeenranta: Karjalaisen Kulttuurin Edistämissäätiö.

Virtaranta, Pertit 1972: Polku sammui. Vienalaiskylien vaiheita rajan molemmin puolin. Helsinki: Kirjayhtymä.

1992: Tverinkarjalaisista nimistä. Suomalais-Ugrilaisen Seuran Toimituksia 209. Helsinki: Suomalais-Ugrilainen Seura.

\section{Puhuiko Suomen sivistyneistö kirjakieltä?}

Kaksikin melko hiljattain, vuonna 2016 ilmestynyttä kirjaa, Erkki Lyytikäisen $\mathrm{Sa}$ notaan tyyliin näin ja Lari Kotilaisen Kielen elämä, toistaa ja siten pitää yllä sitkeää myyttiä, että ainakin melkein koko suomalainen sivistyneistö noin 90-100 vuoden ajan (1870-1880-luvulta 1960-, ellei jopa 1970-luvulle) käytti puhekielenään kielioppien normeja tiukasti noudattavaa kirjakieltä. Tämä käy ilmi seuraavista katkelmista:

Tähän vaihtoehtoon innokkaimmat ruotsinkieliset fennomaanit tarttuivat. He opettelivat sananmukaisesti puhumaan kirjakieltä. Tämä merkitsi sitä, että sivistyneistön puhekieleksi vakiintui kirjakieli sadan vuoden ajaksi. (Lyytikäinen 2016: 207.)

Suomessa yhteiskuntaluokkien statuseron ilmaisemiseen syntyi uusia kei- noja. Kun ei puhuttu enää eri kieliä [= ruotsia ja suomea], alettiin puhua samaa kieltä eri tavalla. [- - ] Kun ruotsinkielinen sivistyneistö alkoi opetella suomea, mallina oli kirjakieli. [- - ] Häviäjiä olivat tavalliset murteet tai toisin termein luonnollinen puhuttu suomi, joka jäi paitsioon lähes sadaksi vuodeksi. (Kotilainen 2016: 149-150.)

Menen lähteille asti (ad fontes): viime vuosikymmenten keskusteluun tämän näkemyksen toi ja sitä on useimmin ja selvimmin pitänyt esillä professori Heikki Paunonen. Lainaan hänen puheenvuoroistaan kahta:

Jatkokehityksen kannalta ratkaisevaa oli, että normatiivisen puhekielen vaatimus saavutti 1800 -luvun lopussa vielä suhteellisen vähälukuisen suomalaisen sivistyneistön kokonaisuu- 